\title{
Effect of Liner Container Size, Root Ball Slicing, and Season of Root Pruning in a Field Nursery on Quercus virginiana Mill. Growth and Anchorage After Transplanting
}

\author{
Edward F. Gilman, Maria Paz, and Chris Harchick
}

\begin{abstract}
Size of liner, root ball slicing when field planting, and field root pruning season were tested with intention of optimizing posttransplant performance of field-grown nursery stock. Trees planted into a field nursery from three container sizes and either root ball sliced or not when shifted to larger containers or planting to the field nursery, and root pruned in the field nursery in either the dormant season or growing season all had the same trunk diameter $(144 \mathrm{~mm})$ and tree height $(6.4 \mathrm{~m})$ three years after transplanting into the landscape. Container size influenced root attributes_including number and orientation-and anchorage rating of field-harvested trees. Trees planted from $11 \mathrm{~L}$ containers required more bending stress to winch trunks evaluated 12 and 25 months after transplanting than larger containers. Percentage of root systems graded as culls was reduced from 88 to 66 by root pruning when field planting, but root pruning resulted in a slight reduction in anchorage rating. Diameter of the ten largest roots at edge of field-harvested root ball decreased with size of container planted into field soil. Root pruning season had no impact on final tree height $(4.3 \mathrm{~m})$ at the conclusion of field production.

Key Words. Anchorage; Bending Stress; Container Volume; Dormant Season; Growing Season; Live Oak; Planting; Quercus virginiana; Root Architecture; Root Depth; Root Pruning; Transplanting.
\end{abstract}

Tree physiological stress from poor root systems can result in root death, poor landscape performance, or tree death following transplanting (Day et al. 2009); this can be costly to tree sellers and upsetting to their customers. Discovering techniques that minimize stress and maximize survival is important for increasing canopy cover and improving efficiency in reforesting the urban landscape. Attributes recognized as important to transplanting field-grown nursery stock include a minimum of roots circling the trunk (Anonymous 2014) and abundance of small diameter roots (Struve et al. 1989). Some live oak trees grown from seed or cuttings (Quercus virginiana Mill. Highrise ${ }^{\mathrm{m}}$ ) in well-drained, sandy nursery fields produce several large roots with few small diameter roots (Gilman et al. 2002). The large roots, especially when oriented downward, can hinder harvesting with a tree spade because blades do not always cut them cleanly. Extra labor is required to sever large roots with a shovel during harvest and can result in loose root balls or tree death in extreme cases.

Root pruning field nursery stock has been used for many years by growers of landscape trees to reduce occurrence of large roots and to generate a dense root system close to the trunk (Watson and Himelick 2013). Nursery growers in sandy soils of the southeastern U.S. coastal plain routinely root prune certain tree taxa in field nurseries with the intention of improving root systems to enhance postdigging survival and reduce leaf drop; traditionally, much of this has been performed during the growing season (Michael Marshall, Marshall Tree Farm, Moriston, Florida, U.S.). However, the autumn 2004 hurricane season in the southeastern U.S. blew over tens of thousands of trees in field nurseries in October and November (personal observation). Some of the instability seemed attributable to root pruning that took place in the previous months (i.e., during the growing season). As a result, researchers 
wanted to determine if root pruning could prove just as effective when performed in dormancy after the hurricane season ended in November. There is limited information on the impact of season of root pruning on root ball quality and transplanting.

Mechanical root pruning strategies have been tested to improve root system quality in containers by reducing occurrence of circling roots. Early work showed that manual root pruning of tree seedlings raised in propagation containers reduced root defects (Harris et al. 1971a; Harris et al. 1971b) and produced more symmetrically distributed lateral roots after reforestation planting (Krasowski 2003). Krasowski and Owens (2000) found that despite a smaller root ball at planting, root systems of mechanically pruned Picea glauca (Moench) Voss seedlings produced more root growth in field soil than control treatments. Gilman et al. (1996) showed that shallow $(2 \mathrm{~cm}$ deep) vertical slicing (often called scoring) from top to bottom on larger $(11 \mathrm{~L})$ root balls of Burford holly (Ilex cornuta 'Burfordii'), when planting to field soil, resulted in a redistribution of roots, not an increase in roots compared with non-pruned controls. Scoring $11 \mathrm{~L}$ container root balls on Q. virginiana as they were shifted into $57 \mathrm{~L}$ containers resulted in an improvement in root system quality (Gilman et al. 2009). Despite these experiences, there were no reports of employing root ball scoring on container liners used for establishing a field nursery and how that might influence landscape transplanting or anchorage. Researchers also wanted to test observations made by nursery operators about root ball attributes and transplant ability of field-grown trees established as larger liner containers ( $57 \mathrm{~L}$ ) instead of the more traditional 3 and $11 \mathrm{~L}$ containers.

The specific objectives of the current study were to determine the effects of tree liner container size, root ball slicing when planting into field soil, and season of field root pruning on root system quality of field-grown nursery stock, as well as survival, growth, and anchorage after landscape planting.

\section{MATERIALS AND METHODS}

\section{Tree Production and Harvesting}

In February 2007, 120 genetically identical Cathedral Oak ${ }^{\oplus}$ live oaks (Quercus virginiana) from stem cuttings, averaging $13 \mathrm{~mm}$ trunk diameter mea- sured $15 \mathrm{~cm}$ from ground (caliper) were obtained from a local central Florida nursery in $11 \mathrm{~L}$ black plastic containers (Accelerator ${ }^{\mathrm{Tm}}$ Nursery Supplies Inc., Chambersburg, Pennsylvania, U.S.). Quercus virginiana was selected for study due to its popularity in warm temperate and semi-tropical climates. Trees had a dominant leader with short temporary branches along the trunk nearly to the ground.

Treatments imposed on these 120 trees were: 1) 40 trees planted directly into field nursery soil (Millhopper fine sand-loamy, siliceous, hyperthermic Grossarenic Paleudults), 2) 40 trees shifted into $38 \mathrm{~L}$ plastic containers (Accelerators with containers touching one another-pot to pot), or 3) 40 trees shifted into $57 \mathrm{~L}$ Accelerator containers pot to pot. Container production facility was located on woven ground cloth several hundred meters from the field nursery in Gainesville, Florida, U.S. (USDA hardiness zone 8b). Container substrate was 20: 60: 20 (New Florida peat: pine bark: sand, by volume; Florida Potting Soil, Inc., Orlando, Florida, U.S.). Fertilizer (18 N-5 $\mathrm{P}_{2} \mathrm{O}_{5}-10$ $\mathrm{K}_{2} \mathrm{O}$, controlled release; Harrells, Inc., Lakeland, Florida, U.S.) was incorporated into substrate prior to shifting at $\left(0.011 \mathrm{~g} / \mathrm{cm}^{3}\right)$, and no other fertilizer was applied in containers. Each was irrigated two to three times, totaling $3.8 \mathrm{~L}$ daily, through one Spot-Spitter (Roberts Irrigation Products, Inc., San Marcos, California, U.S.) per container until autumn 2007 when irrigation frequency and volume was reduced for the dormant season. Trees in containers were secured to a $10 \mathrm{~mm}$ diameter metal stake secured to a trellis system to develop a straight trunk and to hold them erect. Trees planted to the field nursery were secured to the same type of stake driven into the ground without a trellis system. Branches were pruned twice during the growing season to develop a dominant trunk and leader by reducing competing branch length with heading and/or reduction cuts on trees in containers and field nursery through 2009.

The top of the $11 \mathrm{~L}$ root ball on all 120 trees in the study was washed with a stream of water and hand manipulated for a total of 10 seconds to expose circling and potentially girdling roots growing tangent to the trunk in the top $5 \mathrm{~cm}$. These roots were then pulled away from the trunk and cut so the retained root segment was radially oriented straight from the trunk. Half of 
the trees $(20$ for each of three liner sizes $=60$ ) received additional root pruning when planting to the field nursery or shifting to the larger container size. Trees were root pruned by cutting 5 $\mathrm{cm}$ deep into the side of the root ball in six equidistant places from the top of the root ball to the bottom-often referred to as root ball slicing or scoring. The other half of the trees did not receive additional root pruning for field planting or shifting. The trees shifted into the $38 \mathrm{~L}$ containers (Treatment 2, as noted above) were planted into the same field nursery in October 2007, when the trunk diameter averaged $25 \mathrm{~mm}$. The $57 \mathrm{~L}$ containers (Treatment 3 ) were field-planted when trunks reached $33 \mathrm{~mm}$ diameter in January 2008. Root balls that were sliced when shifted were again sliced at planting into field soil in the same manner, while those not sliced when shifted were not sliced when planted into field soil. All trees were planted into the same field with 3.6 $\mathrm{m}$ between rows and $2.6 \mathrm{~m}$ between trees within rows, and were irrigated three times daily during the growing season through two Roberts SpotSpitter spray stakes. Approximately $15 \mathrm{~L}$ irrigation was delivered daily; frequency was reduced to four times weekly in the dormant season.

All trees in the field nursery were root pruned identically but in two different seasons: 1) half were root pruned in the dormant season (Feb., Apr., Oct., Dec. 2008, and Feb. and Apr. 2009), and the other half were root pruned in the growing season (Apr., Jun., Aug., and Oct. 2008, and Apr. and Jun. 2009). At each root pruning, two $1 / 8$ circumference sections opposite one another were cut with a sharp $35 \mathrm{~cm}$ long straight-tipped shovel starting 20 $\mathrm{cm}$ from trunk; each subsequent root pruning was about $2.5 \mathrm{~cm}$ farther from the trunk and rotated another $1 / 8$ clockwise around circumference. Trees were fertilized in the field nursery three times annually with $115 \mathrm{~g}$ of 16 $\mathrm{N}-4 \mathrm{P}_{2} \mathrm{O}_{5}-8 \quad \mathrm{~K}_{2} \mathrm{O}$ spread under the tree crown.

At completion of the field production phase of study (November 2009), half of the trees (mean caliper $=74 \mathrm{~mm}$ ) for each treatment combination (5 randomly chosen complete blocks of 3 liner sizes $\times 2$ slicing treatments $\times 2$ field rootpruning seasons $=60$ trees) were dug with a $0.9 \mathrm{~m}$ (top) diameter mechanical tree spade. Trees were lifted $60 \mathrm{~cm}$ and placed back in the ground in the same hole. The following day, the trunk of each was rocked back and forth at its natural frequency by one person (holding the trunk $1.2 \mathrm{~m}$ from the ground) three times in the north-south direction and then three times in the east-west direction to rate anchorage on a scale devised by the authors $(1$ = loose; 2 = moderately loose; 3 = medium; 4 moderately firm; $5=$ firm). Two ratings were recorded for each tree: north-south and eastwest and the weaker of the two reported. These 60 trees were lifted from the ground in November and December 2009 with a tractor, and soil was washed from roots in the root ball with a stream of water and hand manipulation. Root measurements included the following: diameter of five largest roots $5 \mathrm{~cm}$ inside $11 \mathrm{~L}$ container dimensions; diameter of five largest roots $5 \mathrm{~cm}$ outside 11 L container dimensions; diameter and depth of the ten largest roots measured at the edge of the tree-spaded root ball; number and diameter of straight roots ( $>5 \mathrm{~mm}$ diameter) from trunk (those that turned less than 45 degrees left or right between trunk and edge of the tree-spadedug root ball); total number of roots $>5 \mathrm{~mm}$ diameter at edge of $0.9 \mathrm{~m}$ wide (top diameter) tree-spade-dug root ball; whether root system was a cull, according to Florida Grades and Standards for Nursery Plants (cull = roots larger than one-tenth the trunk diameter in the top half of the root ball circling more than one-third around trunk, Anonymous 1998); and percent trunk circumference circled with roots $>5 \mathrm{~mm}$ diameter.

The other half of the field nursery trees not dug for root measurements (5 complete blocks of 12 treatment combinations $=60$ trees) were moved (transplanted) to an adjacent field in the first week of March 2010 with the same tree spade without a wire basket, burlap, or string commonly used to package field-grown trees. Trunk diameter 15 $\mathrm{cm}$ from ground and tree height were recorded at transplanting. Root balls were irrigated daily for several days by handheld hose until two SpotSpitters were installed to automate $100 \mathrm{~L}$ daily irrigation delivered to the root ball surface starting in the second week of March. Following 06 April 2010, trees were irrigated every other day with periodic dry days to measure physiological stress under water deficit (to be described). 


\section{Landscape Establishment and Anchorage}

Trunk diameter at $15 \mathrm{~cm}$ from ground, and height, on all 60 trees were measured at the end of every growing season in September through 2013 and 2012, respectively. Xylem water potential on all 60 transplanted trees was measured on sunny days at one (April), two (May), five ( $\mathrm{Au}$ gust), and seven (October) months after transplanting into the landscape. Irrigation had been withheld from one (April) to 23 (October) days prior to each measurement, according to Table 5. Xylem potential 12:00 to 14:00 hours was measured with a pressure bomb (Soil Moisture Inc., Santa Barbara, California, U.S.). Terminal portions of current-year twigs in full sun about half way up the south side of the crown were cut about $10 \mathrm{~cm}$ long. Pressure in the air-tight chamber was increased at a constant rate of $30 \mathrm{sec} \cdot \mathrm{MPa}^{-1}$ and was recorded when cut stem surface became uniformly wet. In September 2010, all trees were fertilized with $300 \mathrm{~g}$ of $20 \mathrm{~N}-0 \mathrm{P}_{2} \mathrm{O}_{5}-8 \mathrm{~K}_{2} \mathrm{O}$, and in March and June 2011 and April 2012 with $400 \mathrm{~g}$ spread under the tree crown. No pruning was conducted on trees after transplanting.

Trees were winched to test anchorage in March 2011 and April 2012 (12 and 25 months after transplanting, respectively) from a point approximately $1 \mathrm{~m}$ from the ground until the trunk base tilted five degrees. The cable remained parallel to ground. A $3,629 \mathrm{~kg}$ capacity load cell (SSM-AF-8000; Interface Inc., Scottsdale, Arizona, U.S.) was placed in-line with the winching cable. An inclinometer (model N4; Rieker Inc., Aston, Pennsylvania, U.S.) was mounted to a fabricated steel plate (5.1 $\mathrm{cm} \times 7.6 \mathrm{~cm})$ and the plate was secured to the trunk base $15 \mathrm{~cm}$ from soil surface, which was just above the swollen flare at the trunk base. The cable was winched at $2 \mathrm{~cm} \cdot \mathrm{sec}^{-1}$ until the inclinometer tilted five degrees from the vertical start position; tree was held for 60 seconds while distance was measured from trunk to the deepest point of the soil depression on the leeward side (hinge point) before relaxing the cable. Final angle at the trunk base was recorded as rest angle sixty seconds after relaxing the cable. No rain occurred during the three days required to winch all 60 trees.

Data from load cell and inclinometer were collected at $2 \mathrm{~Hz}$ by Data Acquisition System (National
Instruments Corporation, Austin, Texas, U.S.). Data were displayed in real time during winching on a laptop running LabView software (v: 7.0; National Instruments, Austin, Texas, U.S.). Trunk bending stress was calculated according to Equation 1:

[1] $\quad \sigma=\frac{F \cdot d \cdot R}{\frac{\pi}{4} \cdot R^{4}}$

where

$\sigma=$ bending stress

$F=$ pulling force

$d=$ distance from pulling point to inclinometer

$R=$ trunk radius (calculated as halving diameter measured with a diameter tape at the inclinometer position)

\section{Experimental Design and Statistical Analysis}

The 38 and $57 \mathrm{~L}$ container trees were randomly assigned to positions in the container nursery. Experimental design in the field was a three-way factorial in a randomized complete block design with 3 liner container sizes $\times 2$ root ball slicing treatments at container shifting or field nursery planting $\times 2$ field root pruning seasons $\times 10$ blocks $=120$ trees. Sixty trees (five complete blocks) were harvested and measured at the end of the field production phase trees; the remaining five complete blocks were transplanted. Three-way Analysis of Variance was used for each group to test for significance with container size, root ball slicing, and field root pruning season as main effects, and blocks as a random effect. Results were reported as significant at $P<0.05$ unless indicated. Main effect means were separated by Duncan Multiple Range test; interactions were separated by LSD.

\section{RESULTS}

\section{Field Production}

Liner container size had no impact on tree height in the field nursery in 2008 (Figure 1); however, trees planted from the smallest containers grew more in height in the last year (2009) of field production $(P<0.02)$ resulting in taller trees than those 
planted from the two larger containers (Figure 1). Trunk diameter by the end of 2008 was significantly impacted by liner container size-the significance was due to a slightly larger trunk diameter for trees planted from $11 \mathrm{~L}(50 \mathrm{~mm})$ than $57 \mathrm{~L}(48$ $\mathrm{mm}$ ) containers. This four percent difference is not likely to be meaningful in a production nursery; there was no difference in trunk diameter at the end of the field production period (end of 2009).

Container size influenced anchorage rating and many root attributes when trees were harvested from the field nursery (Table 1). Diameter of the five largest roots measured five $\mathrm{cm}$ inside and five $\mathrm{cm}$ outside of the position of the $11 \mathrm{~L}$ container, number of straight roots, and total number of roots measured at the edge of the $0.9 \mathrm{~m}$ diameter tree-spade-dug root ball were greater for trees planted from the smallest than the largest containers. Mean depth of the ten largest roots measured at the edge of the root ball increased with container size. Anchorage rating immediately following digging with the tree spade decreased with container size (Table 1). In contrast, there was no impact of container size on percentage of trunk circled with roots $>5 \mathrm{~mm}$ diameter $(54 \%)$ or percentage of trees graded as root culls $(76 \%)$, according to Florida Grades and Standards for
Nursery Plants (Anonymous 1998). Other studies have also found a high percentage of trees to be graded as root culls (Gilman et al. 2009).

Root pruning by slicing root balls prior to planting into the field nursery impacted root attributes and anchorage when trees were harvested from the field nursery at the end of 2009 (Table 2). Percentage of root systems graded as culls (Anonymous 1998) was reduced from $88 \%$ to $66 \%$ by root pruning; similarly, percent trunk circled with roots $>5 \mathrm{~mm}$ diameter was reduced by root ball slicing prior to planting into the field nursery. Anchorage rating was reduced slightly to 3.5 from 3.8 by root ball slicing (Table 2). In contrast, slicing prior to field nursery planting had no influence on trunk diameter or tree height growth in the field nursery, and no impact on root diameter, root number, or depth anywhere in the root ball measured when trees were harvested from the field nursery (data not shown).

Container size interacted with root ball slicing prior to field planting (Table 3). Slicing when 11 L liners were shifted into $57 \mathrm{~L}$ containers-and then again when $57 \mathrm{~L}$ were planted into the field nursery-resulted in trees with a slightly smaller trunk diameter $(20 \mathrm{~mm})$ than three other treatment combinations (Table 3). More striking were

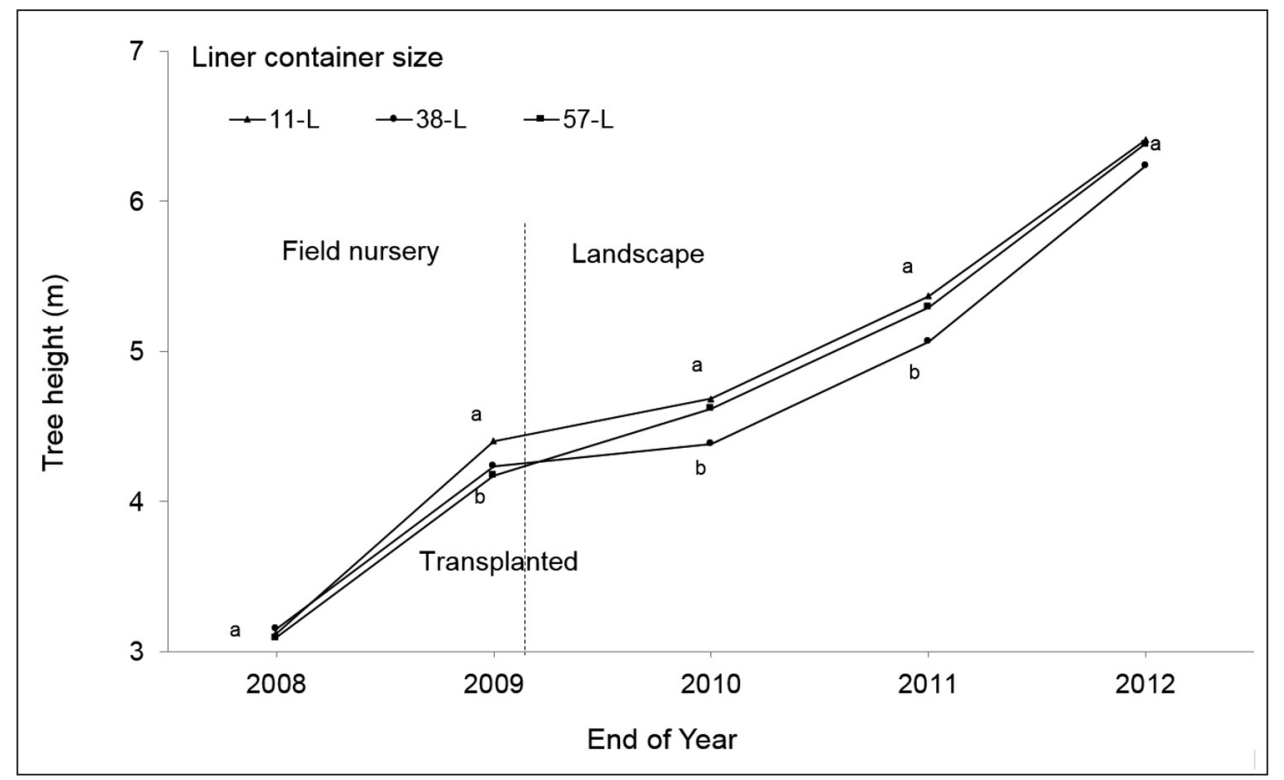

Figure 1. Tree height in September of indicated year in the field nursery originally planted from three liner container sizes and in the three years after transplanting to landscape. Means for a year with different letters are significantly different at $P<0.05 ; n=20$, averaged across root ball slicing prior to field planting and field root pruning season due to insignificant $(P>0.06)$ interaction. 
the differences among treatment combinations in diameter of the ten largest roots measured at the edge of the $0.9 \mathrm{~m}$ wide tree-spade-dug root ball. Diameter of the ten largest roots generally decreased with size of container planted into field soil except that diameter of $38 \mathrm{~L}$ trees not sliced at field planting was similar to trees planted from 57 L containers (Table 3). Moreover, slicing increased diameter of the ten largest roots only for trees planted into the field from 11 L containers, not from the larger sizes. Although field root pruning season impacted height in one year in the field nursery (2008, Table 4), root pruning season had no impact on

Table 1. Effect of liner container size on root growth and anchorage rating at harvest from field nursery.

\begin{tabular}{|c|c|c|c|}
\hline $\begin{array}{l}\text { Liner container } \\
\text { size }(\mathrm{L})^{\mathrm{z}}\end{array}$ & $\begin{array}{l}\text { Diameter five largest } \\
\text { roots inside } 11 \mathrm{~L}(\mathrm{~mm})^{y}\end{array}$ & $\begin{array}{l}\text { Diameter five largest roots } \\
\text { outside } 11 \mathrm{~L}(\mathrm{~mm})^{\mathrm{y}}\end{array}$ & $\begin{array}{l}\text { No. of straight roots }{ }^{\mathrm{x}}>5 \mathrm{~mm} \\
\text { diameter at edge of root ball }\end{array}$ \\
\hline 11 & $35 \mathrm{a}^{\mathrm{u}}$ & $19 a$ & $3.6 \mathrm{a}$ \\
\hline 38 & $33 \mathrm{ab}$ & $18 \mathrm{a}$ & $3.2 \mathrm{ab}$ \\
\hline 57 & $29 \mathrm{~b}$ & $14 \mathrm{~b}$ & $2.1 \mathrm{~b}$ \\
\hline $\begin{array}{l}\text { Liner container } \\
\text { size }(L)^{z}\end{array}$ & $\begin{array}{l}\text { Total no. of roots edge } \\
\text { of root ball }{ }^{\mathrm{w}}\end{array}$ & Depth 10 largest roots $(\mathrm{cm})^{\mathrm{w}}$ & Anchorage rating $^{\mathrm{v}}$ \\
\hline 11 & $243 \mathrm{a}$ & $12 \mathrm{~b}$ & $4.4 \mathrm{a}$ \\
\hline 38 & $200 \mathrm{ab}$ & $14 \mathrm{~b}$ & $3.6 \mathrm{ab}$ \\
\hline 57 & $166 \mathrm{~b}$ & $17 \mathrm{a}$ & $3.1 \mathrm{~b}$ \\
\hline
\end{tabular}

${ }^{\mathrm{z}}$ Trees planted into field nursery in February 2007 from 11 L, October 2007 from 38 L, or January 2008 from 57 L container. Field production concluded end of 2009 when roots and anchorage were measured.

${ }^{y}$ Measured $5 \mathrm{~cm}$ inside or outside former position of the $11 \mathrm{~L}$ liner container.

${ }^{x}$ Roots that turned less than 45 degrees left or right between trunk and edge of the tree-spade-dug root ball.

w Measured at the edge of the $0.9 \mathrm{~m}$ wide tree-spade-dug root ball.

${ }^{\mathrm{v}}$ Anchorage rating the day after digging field nursery trees (with a tree spade) originally planted from the three liner container sizes December 2009 ; $1=$ loose, $5=$ firm; trunk was rocked back and forth at its natural frequency.

u Means in a column with a different letter are statistically different at $P<0.05 ; \mathrm{n}=20$, averaged across root pruning prior to field planting and field root pruning season due to insignificant $(P>0.06)$ interaction.

Table 2. Effect of root ball slicing prior to field planting on root system attributes and anchorage rating at harvest from field nursery.

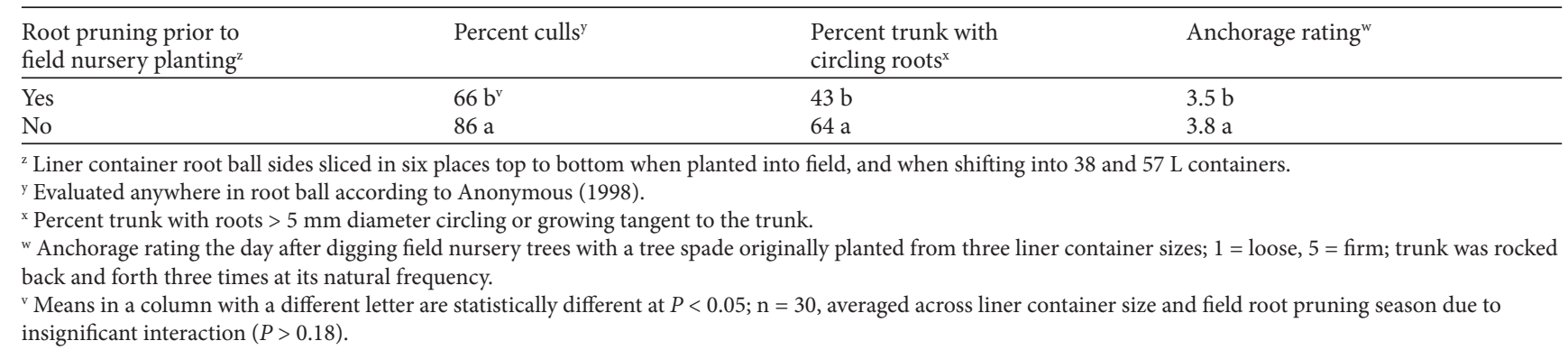

Table 3. Effect of liner container size and root ball slicing prior to field nursery planting on trunk diameter and diameter of largest roots at harvest from field nursery.

\begin{tabular}{|c|c|c|c|}
\hline Liner container size (L) & $\begin{array}{l}\text { Root pruning liner container root balls } \\
\text { prior to field nursery planting }\end{array}$ & $\begin{array}{l}\text { Trunk diameter increase } \\
2008(\mathrm{~mm})\end{array}$ & $\begin{array}{l}\text { Diameter } 10 \text { largest } \\
\text { roots }(\mathrm{mm})^{\mathrm{y}}\end{array}$ \\
\hline 11 & $\begin{array}{l}\text { Yes } \\
\text { No }\end{array}$ & $\begin{array}{l}23 \mathrm{a}^{\mathrm{x}} \\
23 \mathrm{a}\end{array}$ & $\begin{array}{l}21 \mathrm{a}^{\mathrm{x}} \\
18 \mathrm{~b}\end{array}$ \\
\hline 38 & $\begin{array}{l}\text { Yes } \\
\text { No }\end{array}$ & $\begin{array}{l}23 \mathrm{a} \\
21 \mathrm{ab}\end{array}$ & $\begin{array}{l}15 \mathrm{c} \\
13 \mathrm{~cd}\end{array}$ \\
\hline 57 & $\begin{array}{l}\text { Yes } \\
\text { No }\end{array}$ & $\begin{array}{l}20 \mathrm{~b} \\
21 \mathrm{ab}\end{array}$ & $\begin{array}{l}11 \mathrm{~d} \\
11 \mathrm{~d}\end{array}$ \\
\hline
\end{tabular}

${ }^{\mathrm{z}}$ The $11 \mathrm{~L}$ liner container root ball sides sliced in six places top to bottom when planted into field February $2007 ; 38$ and $57 \mathrm{~L}$ sliced similarly when $11 \mathrm{~L}$ shifted to $38 \mathrm{~L}$ or $57 \mathrm{~L}$ and when planted into field, October 2007 and January 2008, respectively. Field production concluded end of 2009 when roots were measured.

${ }^{y}$ Measured at the edge of the $0.9 \mathrm{~m}$ wide tree-spade-dug root ball.

${ }^{\mathrm{x}}$ Means in a column with a different letter are statistically different at $P<0.05 ; \mathrm{n}=20$ (trunk diameter) or 10 (diameter 10 largest roots), averaged across field root pruning season due to insignificant $(P=0.6)$ interaction. 
Table 4. Effect of field nursery root pruning season on tree height, number of roots at edge of root ball, and anchorage rating at harvest from field nursery.

\begin{tabular}{|c|c|c|c|}
\hline $\begin{array}{l}\text { Field nursery root } \\
\text { pruning season }^{z}\end{array}$ & Tree height 2008 (m) & $\begin{array}{l}\text { Total no. roots edge } \\
\text { of dug root bally }\end{array}$ & Anchorage rating ${ }^{x}$ \\
\hline Dormant & $3.2 \mathrm{a}^{\mathrm{w}}$ & $228 \mathrm{a}$ & $3.5 \mathrm{~b}$ \\
\hline Growing & $3.1 \mathrm{~b}$ & $180 \mathrm{~b}$ & $3.8 \mathrm{a}$ \\
\hline
\end{tabular}

final height $(4.3 \mathrm{~m})$ at the conclusion of field production one year later. Root pruning in the field nursery during the dormant season resulted in a significant increase in total number of roots $(>5$ $\mathrm{mm}$ diameter) at the edge of the root ball compared to root pruning during the growing season. Anchorage was less for trees root pruned during the dormant compared to the growing season. Field root pruning season did not interact with either slicing prior to planting into field nursery or liner container size for any measured attribute.

\section{Transplanting}

All trees survived transplanting from the field nursery to the landscape, and there was no visible dieback of twigs or branches in the crown on any trees at any time. No interactions among the three factors tested (liner container size, root ball slicing prior to field nursery planting, or field root pruning season) were significant for any measured post-transplanting attribute, so only the main effects will be discussed. None of the three factors tested impacted trunk diameter at any time after transplanting to the landscape (diameter $=144 \mathrm{~mm}$ three years after transplanting). Height on trees transplanted from $57 \mathrm{~L}$ containers increased more in the first year after transplanting (2010) than from the two other container sizes (Figure 1). Height increased more for trees planted from $38 \mathrm{~L}$ containers than from the other two sizes in the third year after transplanting. The result was that by three years after transplanting (end of 2012), tree height-like trunk diameter-was similar among all treatments.

Liner container size influenced xylem water potential but only in the first month (April 2010) after transplanting to the landscape (Table 5). Xylem on trees planted from $11 \mathrm{~L}$ containers had a lower (more negative) water potential than in trees planted from the larger containers the first and second day after the initial two-day (01-02 April 2010) dry-down period after transplanting. There was no effect of container size during the second dry-down period (03-06 April 2010) or any time afterward through 13 October 2010, even after a 23-day dry-down period (Table 5). Xylem water potential was not affected by slicing prior to field nursery planting $(P>0.71)$ or field root pruning season during field production $(P>0.36)$.

Trees planted from $11 \mathrm{~L}$ containers into nursery field soil and transplanted to the landscape three years later required the largest bending stress to winch trunks to any degree of tilt-except to one degree 12 months (2011) after transplanting (Figure 2). This represented about a 15\% increase in bending stress over the larger liner container sizes 12 and 25 months after transplanting. Rest angle on trees planted from 38 and $57 \mathrm{~L}$ liner containers ( 1.4 and 1.5 degrees, respectively) following winching was greater $(P=0.002)$ than that on trees planted from $11 \mathrm{~L}$ liner containers $(1.2$ degrees). There was no impact of root ball slicing prior to field planting or nursery field root pruning season on tree bending stress required to winch trees to any trunk tilt after transplanting (data not shown). Hinge point in the root plate was not impacted by any factor tested.

\section{DISCUSSION}

Trees planted into a field nursery from three liner container sizes, with root balls either sliced or not when shifted to larger containers or planting into the field nursery, and root pruned in the field nursery in either the dormant season or growing season all had the same trunk diameter $(144 \mathrm{~mm})$ and tree height $(6.4 \mathrm{~m}$, Figure 1$)$ three years after 
Table 5. Xylem water potential (-MPa) one to seven months after transplanting from field nursery to landscape.

\begin{tabular}{|c|c|c|c|c|c|c|c|}
\hline $\begin{array}{l}\text { Liner container } \\
\text { size }(\mathrm{L})^{\mathrm{z}}\end{array}$ & $\begin{array}{l}01 \text { Apr } 2010^{y} \\
\text { (1 day no water) }\end{array}$ & $\begin{array}{l}02 \text { Apr } 2010^{\mathrm{x}} \\
\text { (2 days no water) }\end{array}$ & $\begin{array}{l}05 \text { Apr } 2010^{\mathrm{w}} \\
\text { (3 days no water) }\end{array}$ & $\begin{array}{l}06 \text { Apr } 2010^{\mathrm{v}} \\
\text { (4 days no water) }\end{array}$ & $\begin{array}{l}19 \text { May } 2010^{u} \\
\text { (2 days no water) }\end{array}$ & $\begin{array}{l}06 \text { Aug } 2010^{t} \\
\text { (5 days no water) }\end{array}$ & $\begin{array}{l}13 \text { Oct } 2010^{s} \\
\text { (23 days no water) }\end{array}$ \\
\hline 11 & $1.33 \mathrm{a}^{\mathrm{r}}$ & $1.45 \mathrm{a}$ & 1.33 & 1.14 & 1.98 & 2.01 & 2.30 \\
\hline 38 & $1.14 \mathrm{~b}$ & $1.30 \mathrm{~b}$ & 1.26 & 1.11 & 1.98 & 1.98 & 2.38 \\
\hline 57 & $1.16 \mathrm{~b}$ & $1.21 \mathrm{~b}$ & 1.24 & 1.09 & 2.03 & 2.01 & 2.33 \\
\hline
\end{tabular}

${ }^{z}$ Trees planted into field nursery in February 2007 from 11 L, October 2007 from 38 L, or January 2008 from 57 L container. Trees transplanted from field nursery to landscape in the first week of March 2010.

${ }^{\mathrm{y}}$ Irrigation applied six times daily $(60 \mathrm{~L}$ total) since transplanting prior to 01 April; last irrigated 31 March.

${ }^{x}$ Irrigation $(60 \mathrm{~L})$ applied 02 April to all root balls midafternoon after xylem water potential measured.

${ }^{\text {w }}$ Last irrigated 02 April midafternoon.

$v$ Three times daily irrigation $(45 \mathrm{~L})$ resumed after xylem water potential measured on all trees.

${ }^{u}$ Last irrigated 17 May midafternoon; once daily irrigation $(45 \mathrm{~L})$ resumed after xylem water potential measured on all trees.

${ }^{\mathrm{t}} 7 \mathrm{~cm}$ rainfall 01 August; once daily irrigation $(45 \mathrm{~L})$ resumed after xylem water potential measured on all trees.

${ }^{\mathrm{s}}$ Last irrigated 20 September midafternoon.

${ }^{\mathrm{r}}$ Means in a column with different letters are significantly different at $P<0.05 ; \mathrm{n}=20$, averaged across root pruning prior to field planting and field root pruning season due to insignificant $(P>0.15)$ interaction.

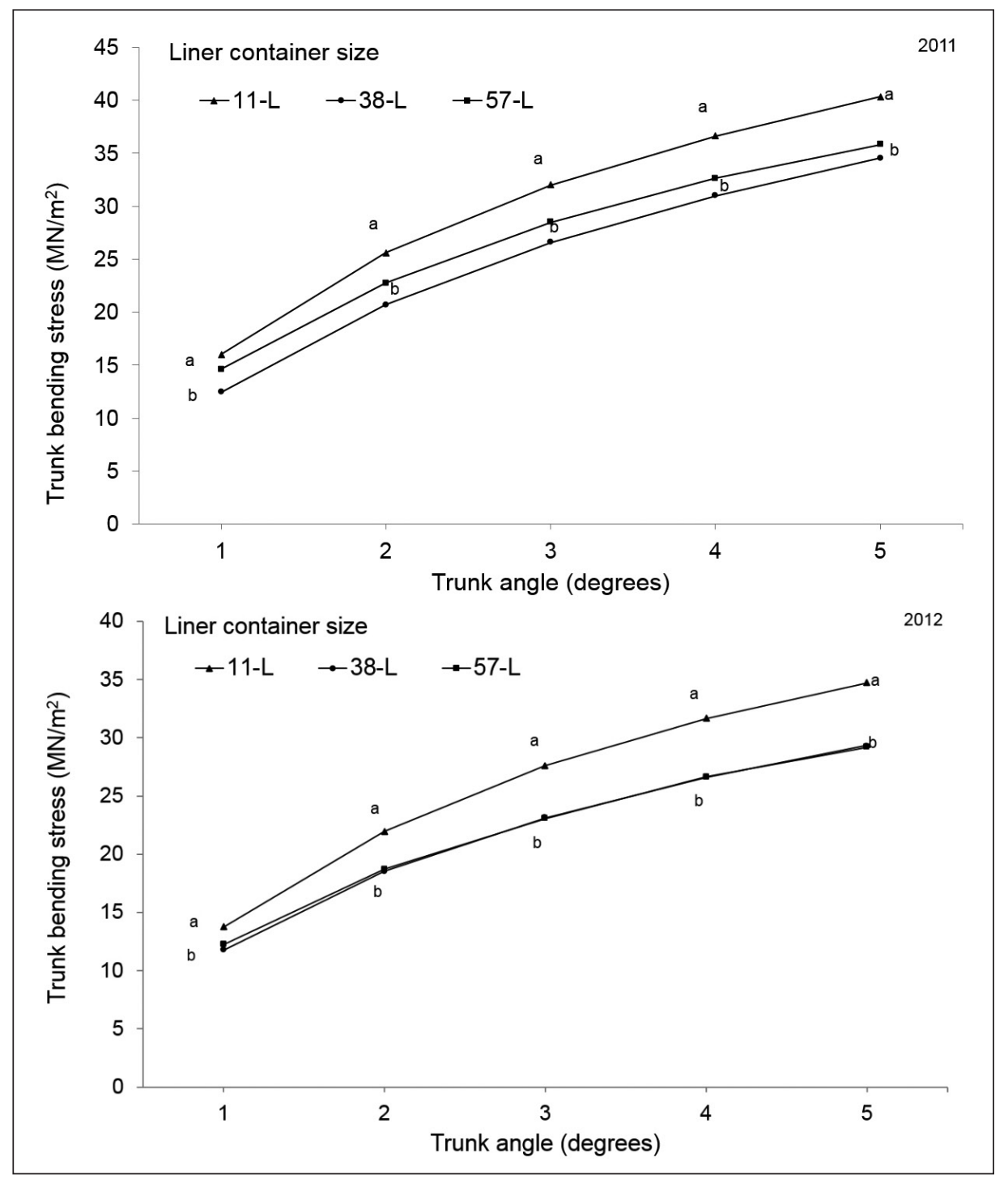

Figure 2. Trunk bending stress while winching trunks to five degrees tilt 12 (2011) and 25 months (2012) after landscape transplanting from a field nursery originally planted from three liner container sizes. Means for a year and angle with different letters are significantly different at $P<0.05$. 
transplanting into the landscape. Despite their similar height three years after transplanting, trees installed from $11 \mathrm{~L}$ containers were taller than those installed from the 38 and $57 \mathrm{~L}$ liners when finished field-grown trees were transplanted to the landscape. Trees from $11 \mathrm{~L}$ containers increased in height slower post-transplanting, perhaps due to the larger and more abundant roots cut when dug from the field nursery (Table 1), which increased water stress (Table 5) slightly. This indicated that despite small differences among liner container sizes in xylem water potential the first month after transplanting (April 2010, Table 5), growth rate from stem cutting to established landscape plant (over a sixyear period) did not depend on tested factors.

Past studies (Watson 1982) suggested that small field-grown nursery stock $(10 \mathrm{~cm}$ trunk diameter) would establish and grow quicker than larger trees (25 cm trunk diameter) transplanted at the same time. Gilman et al. (1998) confirmed that small trunk diameter Q. virginiana trees (6.3 $\mathrm{cm}$ ) planted from nursery containers also grew at a faster rate in the three post-planting years than trees that were larger $(9.4 \mathrm{~cm})$ at planting. Trees in the cited studies were planted at the same point in time and they varied in agelarge trees were larger because they were older.

In contrast, trees in the current study were propagated at the same time and field-planted at staggered times. Although trees from the three container sizes were identically aged throughout the study, those from small containers grew faster in the field nursery in 2008 (Figure 1) to become bigger than trees planted from the larger sizes measured just prior to transplanting to the landscape. Whereas the larger liners were just beginning to establish root systems into nursery field soil in 2008 , trees from $11 \mathrm{~L}$ containers responded with more rapid growth probably because they were in their second year in field soil. Past studies in a similar soil and climate showed that shoot and trunk diameter growth the second or third year after field planting from containers or transplanted from a field nursery often was faster than in the first year (Gilman 1992); studies in cooler climates show a lag in growth of one to three years before pretransplanting growth rate resumed (Watson 1982).
Data from the current study show an association between $Q$. virginiana Cathedral Oak anchorage of fresh-dug finished trees in the field nursery and root system attributes-liner container size impacted these root system attributes. Overall, trees harvested from the field nursery originally planted as small liner containers (11 L containers) had larger, straighter, and shallower roots when compared to those planted into the field nursery from larger containers (57 L containers, Table 1 and Table 3). Therefore, root systems on trees planted as $57 \mathrm{~L}$ containers were more congested from root deflection in the container for a longer period; as a result, they had fewer and smaller roots growing out away from the trunk than trees planted from 11 $\mathrm{L}$ containers. The more congested root system that resulted from planting larger liners corresponded to approximately $30 \%$ lower anchorage rating (3.1) on fresh-dug field nursery trees compared to those planted from the $11 \mathrm{~L}$ containers (4.4 anchorage rating). Also, trees from large liners were $10 \%$ less anchored at 25 months after transplanting to the landscape (Figure 2). Trees from the larger containers would not be as well-anchored to soil because they had smaller diameters and fewer roots at the edge of the root ball (Table 1; Table 3) that positioned fewer roots able to quickly grow into landscape soil as found on Swietenia mahogani L. (Gilman and Harchick 2014). Improved anchorage on trees with a more spreading, less deflected root system-including large straight roots with some being close to the soil surface-has also been demonstrated for Q. virginiana Highrise (Gilman and Weise 2012). Large straight roots resting on mineral soil outside the bounds of the planted container substrate appear to lend more resistance to overturning Acer rubrum L. than trees with large roots deflected (by container wall) close to the trunk (Gilman et al. 2013). These and other studies on Q. virginiana Cathedral Oak (Gilman and Masters 2010) suggest that many straight roots within the root ball with some close to the soil surface, result in stable, well-anchored trees both immediately after digging and 12 to 25 months after landscape planting.

When roots are deflected by the container wall, more mass remains in the original root ball compared to a production strategy that reduces root deflection (Gilman et al. 2015). Deflected roots produce lateral roots that grow into the root ball interior 
or bottom instead of growing away from the trunk in a radial manner, thus reducing the number of roots reaching the side of the current root ball. Current (Table 1; Table 4) and past (Gilman et al. 2013; Gilman et al. 2015) data suggest that trees remaining in a container for a longer period generate a greater portion of their root system in a small soil volume close to the trunk than those planted to field soil earlier, which can lead to less root growth into adjacent landscape soil. This leads to less stable trees.

Root remediation by slicing root balls and removing potentially girdling roots on the top of the liner root ball had little influence on post-transplanting xylem potential, trunk diameter, or tree height; this was also found in other taxa planted from nursery containers (Gilman and Masters 2010; Harris and Day 2010). However, root pruning by slicing the root ball when planting containers into the field nursery increased root system quality in the current study and others (Gilman et al. 2009); despite this increase, $66 \%$ of trees at the end of the field production period graded as culls, and an average of $43 \%$ of trunk circumference remained circled on trees receiving the slicing treatment (Table 2). This data combined with others (Gilman et al. 1996; Weicherding et al. 2007; Gilman and Masters 2010) calls into question the effectiveness of shallow root ball slicing. In a follow-up study with a different taxon, slicing much deeper $(10-12 \mathrm{~cm})$ into the side of a $57 \mathrm{~L}$ container root ball when field planting resulted in a significant increase in number of straight roots, and an increase in anchorage in one of the two postplanting years evaluated (Gilman and Wiese 2012). This was explained as a result of deep slicing, cutting through the previous container's imprint, which not only severed roots growing on the outside of the current container, but cut some that had wrapped the smaller liner container. A more aggressive root pruning program (i.e., root ball shaving, Weicherding 2007) is likely to improve root systems for trees that spend more time in containers prior to planting.

Anchorage of freshly dug (the day prior to anchorage evaluation) trees from the nursery was reduced slightly ( $9 \%$ ) by slicing container root balls at field planting (Table 2) two or three years earlier; however, there was no impact on anchorage 12 or 25 months after transplanting to the landscape. Another related study on Cathedral Oak trees showed that shallow slicing of $170 \mathrm{~L}$ root balls in several places top to bottom-as in the current study-had little or no impact on anchorage measured 36 months after planting (Gilman and Masters 2010). Therefore, the impacts of slicing root balls to remediate root system defects appear to come with only small changes in anchorage, and these may not persist.

Root pruning in the dormant season (Feb., Apr., Oct., and Dec. 2008, and Feb. and Apr. 2009) of Q. virginiana trees growing in the field nursery resulted in a small (9\%) reduction in anchorage immediately following field digging (Table 4) compared to root pruning in the growing season (Apr., June., Aug., and Oct. 2008, and Apr. and Jun. 2009). This occurred despite an increase in number of roots at the edge of the dug root ball compared to growing season root pruning. Perhaps the slight $(P=0.10$, data not shown) reduction in diameter of straight roots on trees pruned in the dormant season was responsible for the small change in anchorage. There are few published studies measuring root response of recently dug field trees to root pruning in different seasons. Those published on crown response showed that, like the current study, season of root pruning had little impact on trunk or shoot growth for several years following planting (Ferree 1992; Gilman 1992).

\section{CONCLUSION}

Despite sizeable differences in many attributes within the root ball imposed by container liner size, slicing the container liner root ball when field planting, and field nursery root pruning timing, there were few differences in trunk and tree height growth in the first three years after transplanting fieldgrown nursery stock to the landscape. This shows the adaptability of this taxon to cultural conditions created in the nursery and suggests that trees can be successfully established from a variety of nursery production systems. The concentration of roots on the interior of the root ball resulting from establishing field nursery trees from large (38 and $57 \mathrm{~L})$ containers compared to the traditional small $(11 \mathrm{~L})$ containers did not reduce water stress (except for one measurement date) when trees were dug from the field nursery. Trees from large liners were slightly less stable when measured the day after digging from the field nursery, but would likely be more stable if they were wrapped in burlap and wire as standard practice. Increased anchorage on trees planted into the field nursery from the smaller 
$(11 \mathrm{~L})$ than from the larger (38 and $57 \mathrm{~L}$ ) liners is likely due to an increase in the number and diameter of straight roots in the root ball, especially those close to the soil surface. Root pruning field-grown Q. virginiana in the dormant season proved as effective at preparing trees for digging as root pruning during the growing season. Survival and growth after transplanting to the landscape was identical for both root pruning seasons, although there was a $9 \%$ unexplained reduction in anchorage and an increase in root number at the edge of the dug root ball as a result of dormant season pruning.

Acknowledgments. Thanks to Marshall Tree Farm, Moriston, Florida, U.S., for supplying tree spade and operator to dig trees.

\section{LITERATURE CITED}

Anonymous. 1998. Florida Grades and Standards for Nursery Plants. Department of Agriculture and Consumer Services, Gainesville Florida.

Anonymous. 2014. American Standard for Nursery Stock (ANSI Z60.1-2004). American Nursery and Landscape Association. Washington, D.C. <www.anla.org/applications/Documents/ Docs/ANLAStandard2004.pdf >

Day, S.D., G.W. Watson, P.E. Wiseman, and J.R. Harris. 2009. Causes and consequences of deep structural roots in urban trees: From nursery production to landscape establishment. Arboriculture \& Urban Forestry 35:182-191.

Ferree, D.C. 1992. Time of root pruning influences vegetative growth, fruit size, biennial bearing, and yield of 'Jonathan' apple. Journal American Society for Horticultural Science 117:198-202.

Gilman, E.F. 1992. Effect of root pruning prior to transplanting on establishment of southern magnolia in the landscape. Journal of Arboriculture 18:197-200.

Gilman, E.F., A. Stodola, and M.D. Marshall. 2002. Production techniques for Highrise ${ }^{\star}$ and seedling live oak. Journal of Environmental Horticulture 20:127-132.

Gilman, E.F., and C. Harchick. 2014. Root system morphology influences lateral stability of Swietenia mahagoni. Arboriculture \& Urban Forestry 40:27-35.

Gilman, E.F., and C. Wiese. 2012. Root pruning at planting and planting depth in the nursery impact root system morphology and anchorage. Arboriculture \& Urban Forestry 38:229-236.

Gilman, E.F., and F. Masters. 2010. Effect of tree size, root pruning, and production method on root growth and lateral stability of Quercus virginiana. Arboriculture \& Urban Forestry 36:281-291.

Gilman, E.F., C. Harchick, and M. Paz. 2009. Root pruning affects tree quality in container-grown oaks. Journal of Environmental Horticulture 27:7-11.

Gilman, E.F., J. Miesbauer, C. Harchick, and R.C. Beeson. 2013. Impact of tree size at planting, mulch, and irrigation on Acer rubrum L. growth and anchorage. Arboriculture \& Urban Forestry 39:173-181.

Gilman, E.F., R.J. Black, and B. Dehgan. 1998. Irrigation volume and frequency and tree size affect establishment rate. Journal of Arboriculture 24:1-9.
Gilman, E.F., T.H. Yeager, and D. Weigle. 1996. Fertilizer, irrigation and root ball slicing affects Burford holly growth after planting. Journal of Environmental Horticulture 14:105-110.

Gilman, E.F., M. Paz, and C. Harchick. 2015. Impact of retention time on root morphology in three nursery container volumes. Arboriculture \& Urban Forestry 41(3):146-154.

Harris, J.R., and S. Day. 2010. Planting depth at onset of container production and subsequent root ball remediation at transplanting of pin oak and linden. HortScience 45:1793-1797.

Harris, R.W., W.B. Davis, N.W. Stice, and D. Long. 1971a. Influence of transplanting time in nursery production. Journal American Society for Horticultural Science 96:109-110.

Harris, R.W., W.B. Davis, N.W. Stice, and D. Long. 1971b. Root pruning improves nursery tree quality. Journal American Society for Horticultural Science 96:105-108.

Krasowski, M.J. 2003. Root system modifications by nursery culture reflect on post-planting growth and development of coniferous seedlings. Forestry Chronicle 79:882-891.

Krasowski, M.J., and J.N. Owens. 2000. Morphological and physical attributes of root systems and seedlings growth in three different Picea glauca reforestation stock. Canadian Journal of Forest Research 30:1669-1681.

Struve, D.K., T.D. Sydnor, and R. Rideout. 1989. Root system configuration affects transplanting of honeylocust and English oak. Journal of Arboriculture 15:129-134.

Watson, G.W. 1982. Tree size affects root regeneration and top growth after transplanting. Journal of Arboriculture 11:37-40.

Watson, G.W., and G. Himelick. 2013. Planting trees. International Society of Arboriculture, Champaign, Illinois, U.S.

Weicherding, P.J., C.P. Giblin, J.H. Gillman, D.L. Hanson, and G. Johnson. 2007. Mechanical root-disruption practices and their effect on circling roots of pot-bound Tilia cordata Mill. and Salix alba L. 'Niobe'. Arboriculture \& Urban Forestry 33:43-47.

\author{
Edward F. Gilman (corresponding author) \\ University of Florida \\ Environmental Horticulture \\ 1533 Fifield Hall \\ Gainesville, Florida 32611, U.S. \\ egilman@ufl.edu
}

Maria Paz

University of Florida

Environmental Horticulture

1533 Fifield Hall

Gainesville, Florida 32611, U.S.

Chris Harchick

University of Florida

Environmental Horticulture

1533 Fifield Hall

Gainesville, Florida 32611, U.S. 
Résumé. La dimension du contenant, la taille de la motte de racines lors de la plantation en pleine terre et la saison au cours de laquelle le cernage des racines a été effectué par la suite ont été évalués avec pour objectif d'optimiser la performance post-transplantation des plants cultivés en pépinière. Les arbres plantés en pépinière provenant de contenants de trois dimensions distinctes et ayant subi ou non une taille de la motte de racines au moment de la transplantation dans des pots plus grands ou plantés directement dans le sol de la pépinière dont les racines ont été taillées soit durant la saison de dormance ou soit durant la saison végétative, possédaient tous le même diamètre au tronc $(144 \mathrm{~mm})$ et la même hauteur $(6,4 \mathrm{~m})$ trois ans après la transplantation sur un site paysagé. La dimension du contenant a influencé certains traits racinaires $-\mathrm{y}$ compris le nombre et l'orientation des racines-, et le taux d'enracinement (ancrage) des arbres récoltés sur le terrain. Le pourcentage de systèmes racinaires classifiés comme rejets a été réduit de 88 à 66 en raison de la taille des racines lors de la plantation sur un site, par contre cette même taille des racines a entraîné une légère réduction du taux d'enracinement (ancrage). Le diamètre des dix plus grosses racines en périphérie de la motte de racines au moment de l'arrachage pour plantation diminue avec la dimension du contenant initialement planté dans la pépinière. La saison où a été effectuée la taille des racines n'a eu aucune incidence sur la hauteur finale de l'arbre $(4,3 \mathrm{~m})$ à la fin de la période de production en pépinière. Les arbres replantés en pépinière qui provenaient de contenants de 11 L nécessitaient une plus grande contrainte de flexion sur les troncs treuillés évalués 12 et 25 mois après leur transplantation que ceux provenant de contenants plus grands.

Zusammenfassung. Mit der Intention, die Leistung von Freilandware aus der Baumschule nach der Verpflanzung zu optimieren wurde die Größe von Linern, die Praxis des Schlitzens von Wurzelballen bei der Verpflanzung und die Saison für Wurzelschnitte in der Baumschule getestet. Bäume, die aus drei verschiedenen Container-Größen kommen und entweder einen geschlitzten oder nicht geschlitzten Wurzelballen während der Verpflanzung in größere Container oder ins Freiland entweder in der Vegetationsruhe oder in der Wachstumsphase hatten, wiesen alle den gleichen Stammdurchmesser und Baumhöhe drei Jahre nach der Verpflanzung in die Landschaft auf. Die Containergröße beeinflusste die Wurzelattribute - einschließlich Anzahl und Orientierung - und die Verankerung von Bäumen, die auf dem Feld geerntet wurden. Der Prozentsatz von Wurzelsystemen, die als Abfall klassifiziert wurden, reduzierte sich von 88 auf 66 bei Wurzelschnitt und Freilandpflanzung, aber der Wurzelschnitt führte zu leichter Reduktion der Verankerung. Die Durchmesser der zehn größten Wurzeln am Rande der aus dem Feld geernteten Wurzelballen sank mit der Größe der Container, die ins Freiland gepflanzt wurden. Die Saison für Wurzelrückschnitt hatte keinen Einfluss auf die finale Baumhöhe $(4,3 \mathrm{~m})$ beim Abschluss der Feldproduktion. Bäume aus 111 Containern erforderten in einer Bewertung nach $12 \mathrm{bzw}$. 25 Monaten mehr Biegebelastung, um den Stamm zu bewegen als größere Container.

Resumen. Se probó el tamaño de la línea de plantación cuando se plantan árboles con bola de raíz y la época de poda de raíces con la intención de optimizar el rendimiento post-trasplante de árboles de vivero. Los árboles plantados en un campo de vivero de tres tamaños de contenedores, si debían ser cortados o no cuando se desplazaran a contenedores más grandes o plantándolos en el campo, y la raíz podada en el campo, ya sea en el período de latencia o estación de crecimiento todos tenían el mismo diámetro del tronco $(144 \mathrm{~mm})$ y la altura de los árboles $(6,4 \mathrm{~m})$ tres años después del trasplante en el paisaje. El tamaño del contenedor influyó en los atributos de la raíz - incluyendo número y la orientación - y calificación de anclaje de los árboles del campo. El porcentaje de sistemas de raíces clasificado como sacrificios se redujo de 88 a la
66 mediante la poda de raíces cuando crecieron en el campo, pero la poda de raíces resultó en una ligera disminución en la calificación de anclaje. El diámetro de diez de las raíces más grandes en el borde del cepellón en el campo disminuyó con el tamaño del contenedor del árbol plantado en suelo. La temporada de poda de raíces no tuvo impacto en la altura final del árbol (4.3 m). Los árboles plantados de contenedores de $11 \mathrm{~L}$ requirieron más fuerza de flexión en los troncos evaluados 12 y 25 meses después del trasplante que los árboles más grandes de contenedores. 